\title{
Effects of silicafume and fly ash on properties of alumina cement
}

\author{
Hong Luu Thi ${ }^{1}$, Long Luong Duc ${ }^{1}$, Cham Trinh Thi ${ }^{1}$, Luan Ta $\operatorname{Van}^{1}$ and Qui Duong \\ Thanh ${ }^{2, *}$ \\ ${ }^{1}$ Vietnam Institute for Building Materials, 235 Nguyen Trai Road, Thanh Xuan District, Hanoi, \\ Vietnam \\ ${ }^{2}$ Moscow State University of Civil Engineering, Yaroslavskoe shosse, 26, Moscow, 129337, Russia
}

\begin{abstract}
Alumina cement which was used in this investigation contains about $56 \%$ of $\mathrm{Al}_{2} \mathrm{O}_{3}$ in the component. Early compressive strength alumina cement at 1 and 3 days can be achieved of $85 \%$ compressive strength value at 28 days. After a long period of hydration, the compressive strength of alumina cement harder decreased due to the releasing process of aluminum hydroxide $\left[\mathrm{Al}(\mathrm{OH})_{3}\right]$ to the outside environment $[1,4,11]$. To improve and maintain the long - lasting compressive strength of alumina cement harden, new binders would be created $\mathrm{SiO}_{2}-\mathrm{Al}_{2} \mathrm{O}_{3}$ and among $\mathrm{CaO}-\mathrm{SiO}_{2}-\mathrm{Al}_{2} \mathrm{O}_{3}$. The new binders would exist sustainably in the cement harden as a result of the chemical reaction between the product of hydrated cement called gel $\left[\mathrm{Al}(\mathrm{OH})_{3}\right]$ with micro silica (amorphous $\mathrm{SiO}_{2}$ ) [4]. This report demonstrates the result of the investigation which is about the effect of silica fume and fly ash on alumina cement.
\end{abstract}

\section{Introduction}

Alumina Cement is investigated and manufactured by many countries all over the world with the purpose of producing refractory mortars and concretes $[1,11,13]$. Furthermore, it is used to make rapid refractory mortars, rapid concretes and anti-shrinkage concretes. Besides, it can also be made use of in the places which have to be quickly constructed; therefore, the construction would not take much time it can put the works into use in a short time $[1,3,11,12]$.

Alumina cement is mentioned in this report, that is manufactured from resources of Viet Nam domestic as: Ha Nam limestone, Tan Rai alumina oxide, Dong Anh factory's mud alumina and PhuTho kaolin. The components were properly calculated, ground and heated in 1400 Celsius degrees to make alumina cement clinker [4].

The proportion of silica fume and fly ash accounted for 5-20\% in the components while $0.8 \%$ polycacboxylate was used.

\footnotetext{
* Corresponding author: quiduongthanh@gmail.com
} 


\section{The research methods and materials}

\subsection{The research methods}

This study used standard methods and physicochemical methods to determine the properties of materials. The methods of investigation are as follows:

- Chemical composition of Alumina cement is determined according to Viet Nam standard TCVN 6533 - Refractory alumosilicate -Test method for chemical analysis.

- Chemical composition of fly ash is determined according to Viet Nam standard TCVN 8262 - Fly ash: Test method for chemical analysis.

- Chemical composition of silica fume is determined according to Viet Nam standard TCVN 141 - Portland Cements - Test method for chemical analysis.

- Specific gravity, fineness of fly ash, silica fume and alumin cement is determined according to Viet Nam standard TCVN 4030 - Cements: Test method for determination of fineness.

- Setting time of alumina cement is determined according to Viet Nam standard TCVN 6017 - Cements: Test method for determination of setting time.

- Compressive strength of alumina cement is determined according to Viet Nam standard TCVN 6016 - Cements: Test method for determination of strength.

- Properties of chemical admixture is determined according to Viet Nam standard TCVN 8826 - Chemical admixtures for concrete.

- Particle size distribution of fly ash and silica fume is determined by Couter particle size (Laser Particle Size Analyzer) Model: LA-960A - Manufacturer: Horiba - JAPAN.

- Minerals (phases) composition of alumina cement is determined by the XRD method (X Ray Diffraction) by D2 PHARSER - Brucker.

- Particle shape of fly ash and silica fume is determined by scanning electronmicroscope (SEM). S-4800, HITACHI

\subsection{The materials is used in the investigation}

\subsubsection{Alumina cement}

The chemical composition, minerals (phases) composition and physical properties of alumina cement areshown on Table 2.1; 2.2; 2.3 and Fig. 2.1.

Table 2.1. The chemical composition of alumina cement

\begin{tabular}{|c|c|c|c|c|c|c|c|c|c|}
\hline $\mathbf{S i O}_{\mathbf{2}}$ & $\mathbf{F e}_{\mathbf{2}} \mathbf{O}_{\mathbf{3}}$ & $\mathbf{A l}_{\mathbf{2}} \mathbf{O}_{\mathbf{3}}$ & $\mathbf{C a O}$ & $\mathbf{M g O}$ & $\mathbf{S O}_{\mathbf{3}}$ & $\mathbf{K}_{\mathbf{2}} \mathbf{O}$ & $\mathbf{N a}_{\mathbf{2}} \mathbf{O}$ & $\mathbf{T i O}_{\mathbf{2}}$ & $\mathbf{M K N}$ \\
\hline 10.28 & 0.51 & 56.04 & 30.45 & 0.76 & 0.0 & 0.10 & 0.12 & 0.07 & 0.69 \\
\hline
\end{tabular}

Table 2.2. The physical properties of alumina cement

\begin{tabular}{|c|c|c|c|}
\hline \multicolumn{3}{|c|}{ Fineness } & \multirow{2}{*}{$\begin{array}{c}\text { Specific gravity } \\
\mathbf{g} / \mathbf{c m}^{3}\end{array}$} \\
\hline $\begin{array}{c}\text { Sieve } \\
45 \mu \mathrm{m}, \boldsymbol{\%}\end{array}$ & $\begin{array}{c}\text { Residue of sieve } \\
80 \mu \mathrm{m}\end{array} \mathbf{\%}$ & Blaine $\left(\mathbf{c m}^{2} / \mathbf{g}\right)$ & \\
\hline 26.85 & 8.50 & & 3.1 \\
\hline
\end{tabular}

Table 2.3. Minerals (phases) composition of alumina cement

\begin{tabular}{|c|c|c|c|c|c|}
\hline $3 \mathrm{CaO} . \mathrm{Al}_{2} \mathrm{O}_{3}$ & $\mathrm{CaO} . \mathrm{Al}_{2} \mathrm{O}_{3}$ & $\begin{array}{c}2 \mathrm{CaO} \mathrm{Al}_{2} \mathrm{O}_{3} \cdot \\
\mathrm{SiO}_{2} \text { (gehlenite) }\end{array}$ & $5 \mathrm{CaO} .3 \mathrm{Al}_{2} \mathrm{O}_{3}$ & $\mathrm{CaO} .2 \mathrm{Al}_{2} \mathrm{O}_{3}$ & $\begin{array}{c}\text { Amorphous } \\
\text { phase }\end{array}$ \\
\hline 5 & 46 & 28 & 3 & 8 & 10 \\
\hline
\end{tabular}




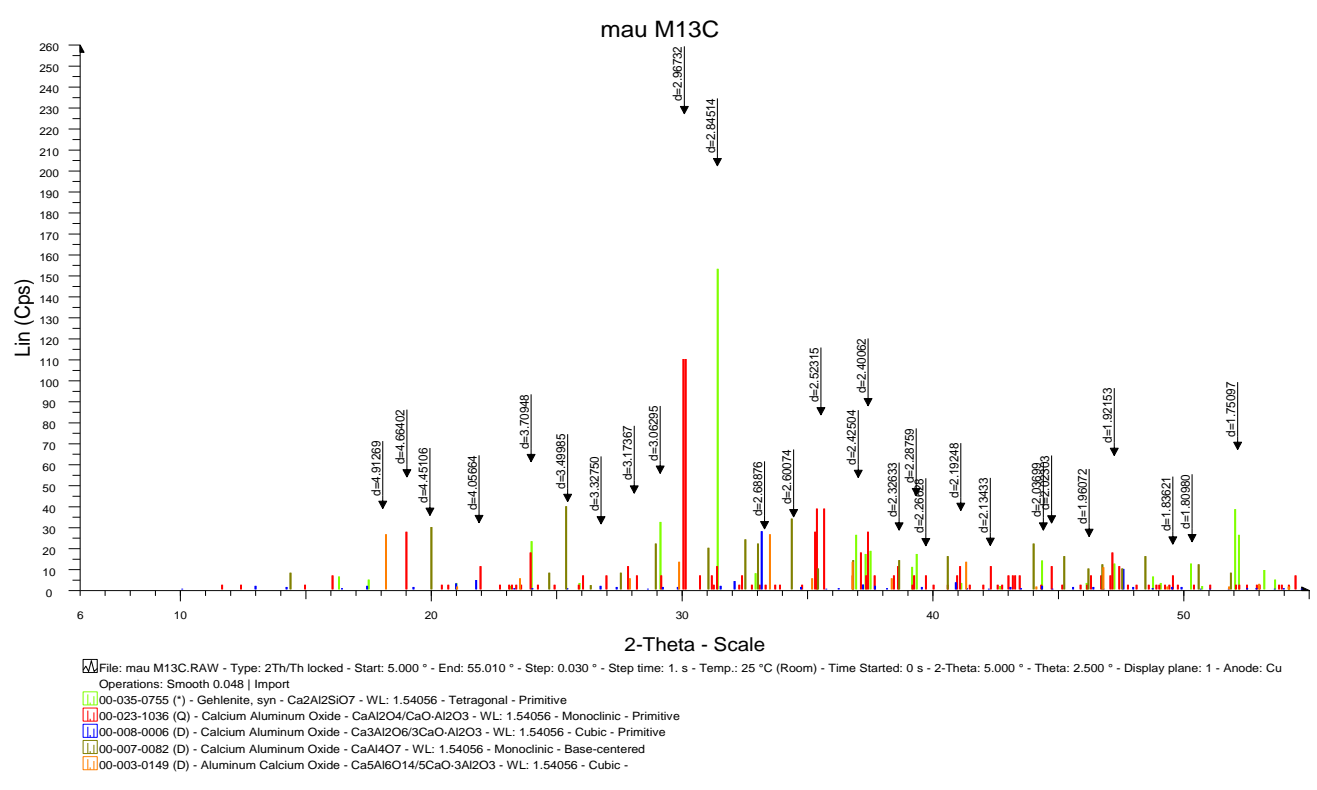

Fig. 2.1. XRD analysis of alumina cement

\subsubsection{Fly ash}

The chemical composition and mechanical properties of fly ash is shown on Table 2.4; 2.5

Table 2.4.The chemical composition of fly ash

\begin{tabular}{|c|c|c|c|c|c|c|c|c|c|}
\hline $\mathbf{M K N}$ & $\mathbf{S i O}_{\mathbf{2}}$ & $\mathbf{F e}_{\mathbf{2}} \mathbf{O}_{\mathbf{3}}$ & $\mathrm{Al}_{\mathbf{2}} \mathbf{O}_{\mathbf{3}}$ & $\mathbf{C a O}$ & $\mathbf{M g O}$ & $\mathbf{S O}_{\mathbf{3}}$ & $\mathbf{K}_{\mathbf{2}} \mathbf{O}$ & $\mathbf{N a}_{\mathbf{2}} \mathbf{O}$ & $\mathbf{T i O}_{\mathbf{2}}$ \\
\hline 1.73 & 49.69 & 7.18 & 18.64 & 11.34 & 4.23 & 0.68 & 1.7 & 3.49 & 0.2 \\
\hline
\end{tabular}

Table 2.5. Physical properties of fly ash

\begin{tabular}{|c|c|c|c|c|c|}
\hline \multirow{2}{*}{ Wet content, \% } & \multirow{2}{*}{ Specific gravity, $\mathbf{g} / \mathrm{cm}^{\mathbf{3}}$} & \multicolumn{2}{|c|}{ Blaine, $\mathbf{c m}^{\mathbf{2}} \mathbf{g}$} & \multicolumn{2}{c|}{ Residue of sieve (\%) } \\
\cline { 3 - 6 } & & TCVN 4030 & ASTM C115 & $\mathbf{0 . 0 8} \mathbf{~ m m}$ & $\mathbf{0 . 0 4 5} \mathbf{~ m m}$ \\
\hline 0.14 & 2.23 & 2580 & 2450 & 4.15 & 16.2 \\
\hline
\end{tabular}

\subsubsection{Silica fume}

The chemical and physical properties of Silica fume which was imported from Germany to show on Table 2.6. Particle size, particle shape of silica fume is shown on Fig. $2.2 ; 2.3$.

Table 2.6. The chemical and physical properties of silica fume

\begin{tabular}{|c|l|c|c|c|}
\hline No. & Properties & Unit & Results & Test method \\
\hline 1 & Loss on ignition $(\mathrm{MKN})$ & $\%$ & 4.82 & TCVN 8827:2011 \\
\hline 2 & Silic dioxide content, $\mathrm{SiO}_{2}$ & $\%$ & 91.84 & TCVN 8827:2011 \\
\hline 3 & $\begin{array}{l}\text { Active compressive strength index } \\
- \text { At 7 days compared with control } \\
\text { sample (ordinary cement). } \\
- \text { At 28 day compared with control }\end{array}$ & $\%$ & 115 & TCVN 8827:2011 \\
\hline
\end{tabular}




\begin{tabular}{|l|l|c|c|c|}
\hline & sample (ordinary cement). & & 115 & \\
\hline 4 & Residue of sieve, $45 \mu \mathrm{m}$ & $\%$ & 6.4 & TCVN 8827:2011 \\
\hline
\end{tabular}

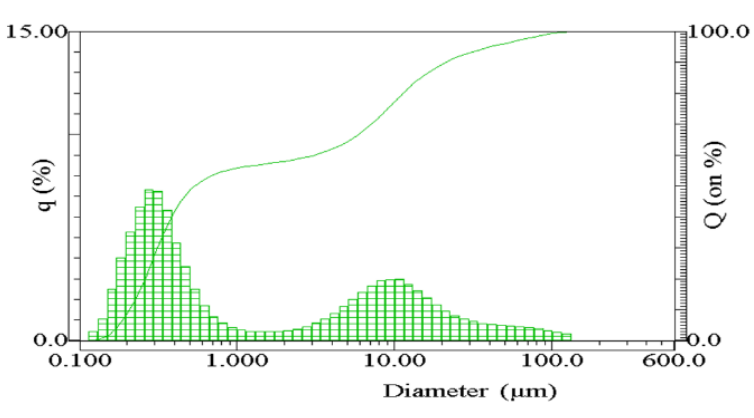

Fig. 2.2. Particle size distribution of silica fume

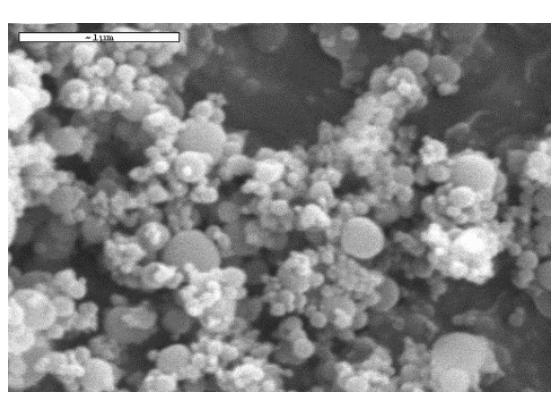

Fig. 2.3. SEM analysis of silica fume

\subsubsection{Chemical admixture}

Super plasticizer admixture bases on polycarboxylateto be signed type of $\mathrm{HS}_{3} \mathrm{O}_{1}$. It recommended dosage from $0,6 \%$ to $1,2 \%$ according to weight components. In this investigation is used $0,8 \%$ of $\mathrm{HS}_{3} \mathrm{O}_{1}$ content compared cement weight. The properties of chemical admixture is shown on Table 2.7

Table 2.7. The properties of chemical admixture

\begin{tabular}{|c|c|}
\hline The properties & Value \\
\hline Density & $1.0 \mathrm{~g} / \mathrm{cm}^{3}, 23^{\circ} \mathrm{C}$ \\
\hline $\mathrm{pH}$ & $6.0-8.5$ \\
\hline Solid content & $40 \pm 1 \%$ \\
\hline $\mathrm{CL}$ & $0,005 \%$ \\
\hline $\mathrm{Na}_{2} \mathrm{SO}_{4}$ & $0.1 \%$ \\
\hline $\mathrm{Na}_{2} \mathrm{O}+\mathrm{K}_{2} \mathrm{O} 0,658$ & $2.5 \%$ \\
\hline
\end{tabular}

\section{Results and discussions}

Alumin cements were replaced from 5 to $20 \%$ fly ash or silica fume and used $0.8 \%$ polycarboxylate by weight content, which have component ratios shown on Table 3.1.

Table 3.1. Component ratios used fly ash, silica fume and polycarboxylate

\begin{tabular}{|c|c|c|c|c|c|}
\hline No & Sample signs & $\begin{array}{c}\text { Alumina cement } \\
(\%)\end{array}$ & Silicafume (\%) & $\begin{array}{l}\text { Fly ash } \\
(\%)\end{array}$ & Polycarboxylate(\%) \\
\hline 1 & 0 & 100 & - & - & - \\
\hline 2 & $\mathrm{P}$ & 100 & & & 0.8 \\
\hline 3 & $\mathrm{PS}_{5}$ & 95 & 5 & - & 0.8 \\
\hline 4 & $\mathrm{PS}_{10}$ & 90 & 10 & - & 0.8 \\
\hline 5 & $\mathrm{PS}_{15}$ & 85 & 15 & - & 0.8 \\
\hline 6 & $\mathrm{PS}_{20}$ & 80 & 20 & - & 0.8 \\
\hline
\end{tabular}




\begin{tabular}{|c|c|c|c|c|c|}
\hline No & Sample signs & $\begin{array}{c}\text { Alumina cement } \\
(\boldsymbol{\%})\end{array}$ & Silicafume (\%) & $\begin{array}{l}\text { Fly ash } \\
(\boldsymbol{\%})\end{array}$ & Polycarboxylate(\%) \\
\hline 7 & $\mathrm{PF}_{5}$ & 95 & - & 5 & 0.8 \\
\hline 8 & $\mathrm{PF}_{10}$ & 90 & - & 10 & 0.8 \\
\hline 9 & $\mathrm{PF}_{15}$ & 85 & - & 15 & 0.8 \\
\hline 10 & $\mathrm{PF}_{20}$ & 80 & - & 20 & 0.8 \\
\hline 11 & $\mathrm{~F}_{5}$ & 95 & - & 5 & 0 \\
\hline 12 & $\mathrm{~F}_{10}$ & 90 & - & 10 & 0 \\
\hline 13 & $\mathrm{~F}_{15}$ & 85 & - & 15 & 0 \\
\hline 14 & $\mathrm{~F}_{20}$ & 80 & - & 20 & 0 \\
\hline
\end{tabular}

Notes: $\mathrm{O}$ is signed the ordinary alumina cement sample; $\mathrm{P}$ is signed ordinary alumina cement used polycarboxylate; PS is signed alumina cement samples used silica fume and polycarboxylate; PF is signed alumina cement samples used fly ash and polycarboxylate; $\mathrm{F}$ is signed alumina cement samples used fly ash.

\subsection{Study results affected fly ash content to alumina cement properties}

Fly ash and polycarboxylate affected consistence, setting time and compressive strength of alumina cement, which is shown on Table 3.2.

Table 3.2. The properties of alumina cement used fly ash on component

\begin{tabular}{|l|c|c|c|c|c|c|c|c|}
\hline \multirow{2}{*}{$\begin{array}{l}\text { Sample } \\
\text { signs }\end{array}$} & \multirow{2}{*}{$\begin{array}{c}\text { Consistence, } \\
\text { \% }\end{array}$} & \multicolumn{2}{|c|}{$\begin{array}{c}\text { Setting time, } \\
\text { Min. }\end{array}$} & \multicolumn{5}{|c|}{ Compressive strength } \\
\cline { 3 - 9 } & & initial & Finitial & $\mathbf{6}$ hour & $\mathbf{1}$ day & $\mathbf{3}$ days & $\mathbf{7}$ days & $\begin{array}{c}\mathbf{2 8} \\
\text { days }\end{array}$ \\
\hline 0 & 40 & 120 & 140 & 16.12 & 29.00 & 43.50 & 49.60 & 58.94 \\
\hline $\mathrm{P}$ & 27.6 & 105 & 130 & 21.05 & 29.25 & 44.56 & 49.80 & 60.12 \\
\hline $\mathrm{PF}_{5}$ & 28.6 & 80 & 105 & 35.00 & 39.62 & 57.20 & 61.00 & 80.31 \\
\hline $\mathrm{PF}_{10}$ & 30 & 80 & 110 & 29.62 & 36.50 & 49.81 & 57.18 & 65.93 \\
\hline $\mathrm{PF}_{15}$ & 32 & 85 & 100 & 17.00 & 26.00 & 41.81 & 41.75 & 47.00 \\
\hline $\mathrm{PF}_{20}$ & 33 & 85 & 95 & 15.87 & 25.97 & 36.25 & 40.31 & 40.34 \\
\hline $\mathrm{F}_{5}$ & 34 & 80 & 110 & 30.00 & 39.68 & 47.31 & 60.75 & 75.42 \\
\hline $\mathrm{F}_{10}$ & 35 & 80 & 100 & 28.56 & 37.80 & 46.43 & 65.06 & 64.51 \\
\hline $\mathrm{F}_{15}$ & 35 & 80 & 95 & 18.62 & 28.18 & 33.06 & 43.50 & 43.64 \\
\hline $\mathrm{F}_{20}$ & 36 & 85 & 100 & 16.43 & 25.12 & 29.93 & 34.75 & 36.56 \\
\hline
\end{tabular}

The diagrams which were shown relation between fly ash content and cement properties on Fig. 3.1 and 3.2 from results on Table 3.2. 


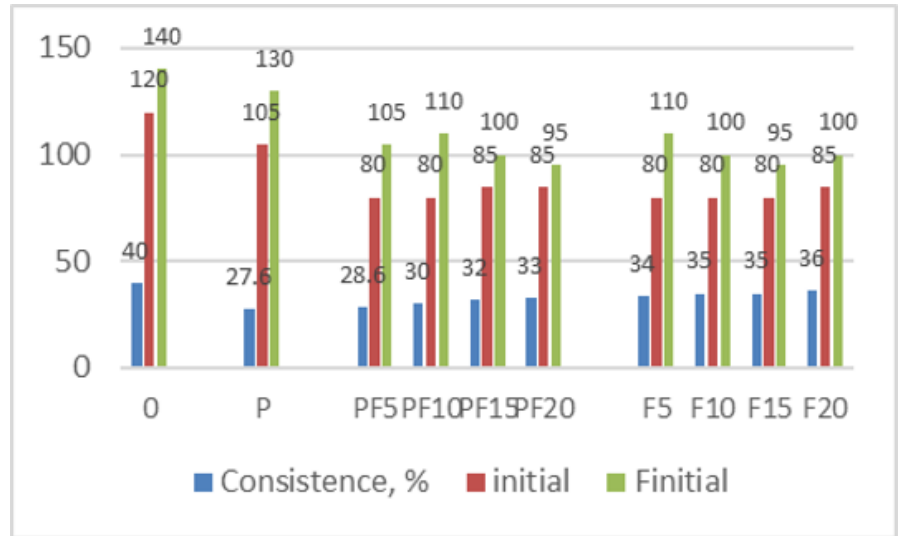

Fig. 3.1. Fly ash content affected to consistence and setting time of alumina cement paste

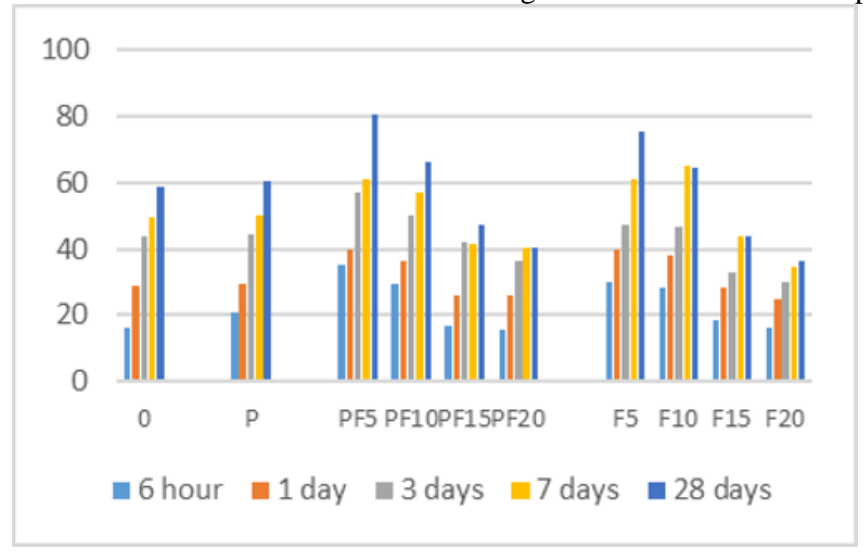

Fig. 3.2. Fly ash content affected to compressive strength of alumina cement harden

Polycarboxylate used in alumina cement content that is reduced water requirement of cement paste (reducing 30\% water compared to ordinary alumina cement). However, alumina cement contains polycarboxylate did not increase its compressive strength at all.

The cause of this phenomenon is that polycarboxylatelatches on to surface of cement particles, which helps slippery cement particles and reduces the need water in the cement paste.Polycarboxylate also reduced initial setting time of alumina cement paste (reducing $12.5 \%$ compared ordinary alumina cement paste), but final setting time of alumina cement paste reduced no more than with controlled alumina cement.

Fly ash on alumine cement component reduced water requirement and setting time of cement paste (reducing from 10 to $15 \%$ water requirement compared water requirement of ordinary alumina cement). The reducing setting time is on surface of fly ash particles keeping water, so it is limited flexible cement paste.

Alumina cement which used the combination of fly ash and polycarboxylateto would reduce water requirement, setting time of cement paste. (Reducing from $17.5 \%$ to $25 \%$ compared ordinary alumina cement paste). This phenomenon reduced water requirement and setting time of alumina cement paste the same as above explained.

Alumina cement contains from 5 to $10 \%$ fly ash which were increasing more compressive strength than ordinary alumina cement. Increasing ratio of compressive strength at 6 hour was reached maximum that is of 54\%. However alumina cement contains to $20 \%$ fly ash which was reducing less compressive strength than ordinary alumina cement. 


\subsection{Study results affected silica fume to cement properties}

The results affected Silicafume to consistence, setting time and compressive strength of alumina cement shown on Table 3.3.

Table 3.3. The properties of alumina cement contained silica fume

\begin{tabular}{|c|c|c|c|c|c|c|c|c|}
\hline \multirow{2}{*}{$\begin{array}{l}\text { Sample } \\
\text { signs }\end{array}$} & \multirow{2}{*}{$\begin{array}{c}\text { Consistence, } \\
\mathbf{\%}\end{array}$} & \multicolumn{2}{|c|}{$\begin{array}{c}\text { Setting time, } \\
\text { Min. }\end{array}$} & \multicolumn{5}{|c|}{ Compressive strength } \\
\cline { 3 - 9 } & & Initial & Finitial & $\mathbf{6}$ hour & $\mathbf{1}$ day & $\mathbf{3 ~ d a y s}$ & $\mathbf{7}$ days & $\begin{array}{c}\mathbf{2 8} \\
\text { days }\end{array}$ \\
\hline 0 & 40 & 120 & 140 & 16.12 & 29.00 & 43.50 & 49.60 & 58.94 \\
\hline $\mathrm{P}$ & 27.6 & 105 & 130 & 21.05 & 29.25 & 44.56 & 49.80 & 60.12 \\
\hline $\mathrm{PS}_{5}$ & 27.3 & 95 & 105 & 29.18 & 35.40 & 51.00 & 60.12 & 77.43 \\
\hline $\mathrm{PS}_{10}$ & 27.3 & 80 & 90 & 31.06 & 39.30 & 52.15 & 60.62 & 85.00 \\
\hline $\mathrm{PS}_{15}$ & 28 & 80 & 85 & 27.10 & 35.80 & 44.75 & 61.25 & 73.94 \\
\hline $\mathrm{PS}_{20}$ & 28.6 & 60 & 70 & 23.50 & 27.00 & 40.25 & 49.50 & 66.81 \\
\hline
\end{tabular}

The diagrams were shown relation between silica fume content with cement properties on Fig. 3.3 and 3.4 from results on Table 3.3

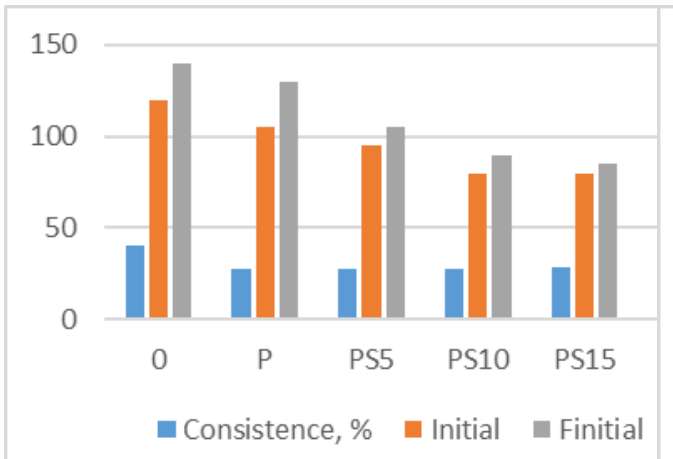

Fig. 3.3. Silica fume content affected to consistence and setting time of alumina cement paste

Silica fume on alumina cement component also reduced water requirement and setting time of cement paste (reducing from $28.5 \%$ to $31 \%$ water requirement compared by control alumina cement). It is the same as alumina cement which contains polycarboxylate. Silicafume cements can reduce more water requirement than fly ash cements cause all silica fume particles are sphericities they can be created effectivity roller of silica fume and cement particles together.

Alumina cement contains from 5 to $15 \%$ silica fume which were increasing more compressive strength than ordinary alumina cement. Increasing ratio of compressive strength at 6 hours was reached maximum that is $48 \%$ of sample contains $10 \%$ silica fume in component. However, alumina cement contains to $20 \%$ silica fume which was reducing less compressive strength than ordinary alumina cement

\subsection{SEM and XRD analysis results of alumina cement contained silica fume, fly ash and control sample at 1 and 3 days}

SEM analysis results of the cement samples were stored at 1 and 3 days which were shown on Figures from 3.5 to 3.7 


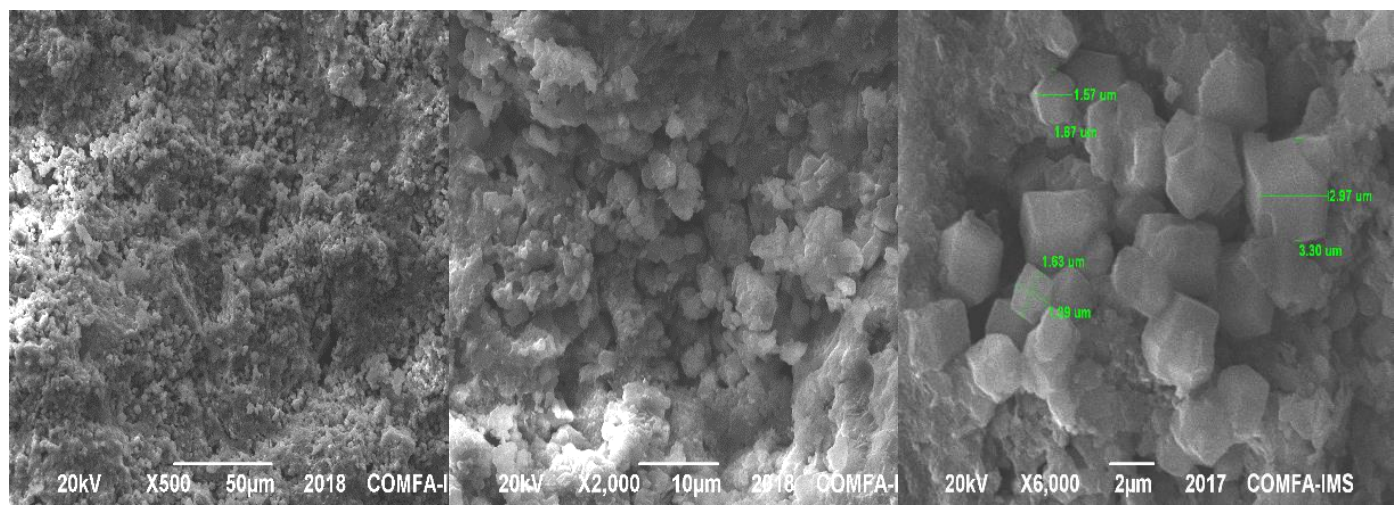

Fig. 3. 5. SEM analysis of ordinary alumina cement harden at 1 day

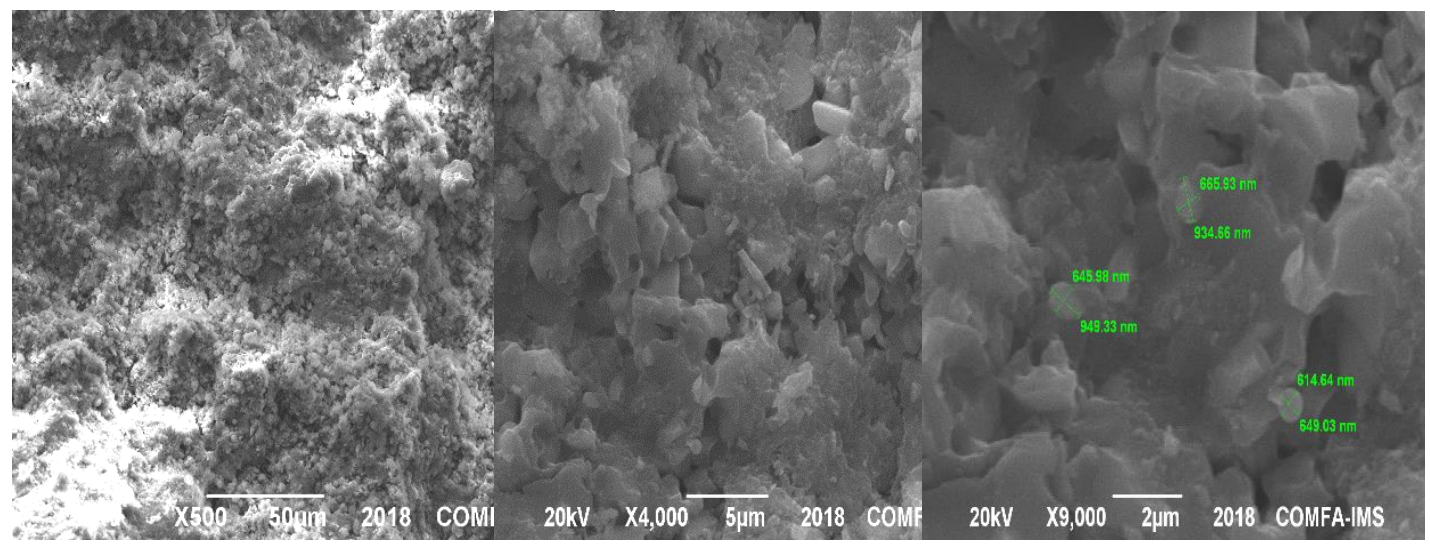

Fig.3.6. SEM analysis of alumina cement contained $10 \%$ fly ash and polycarboxylate at 1 day

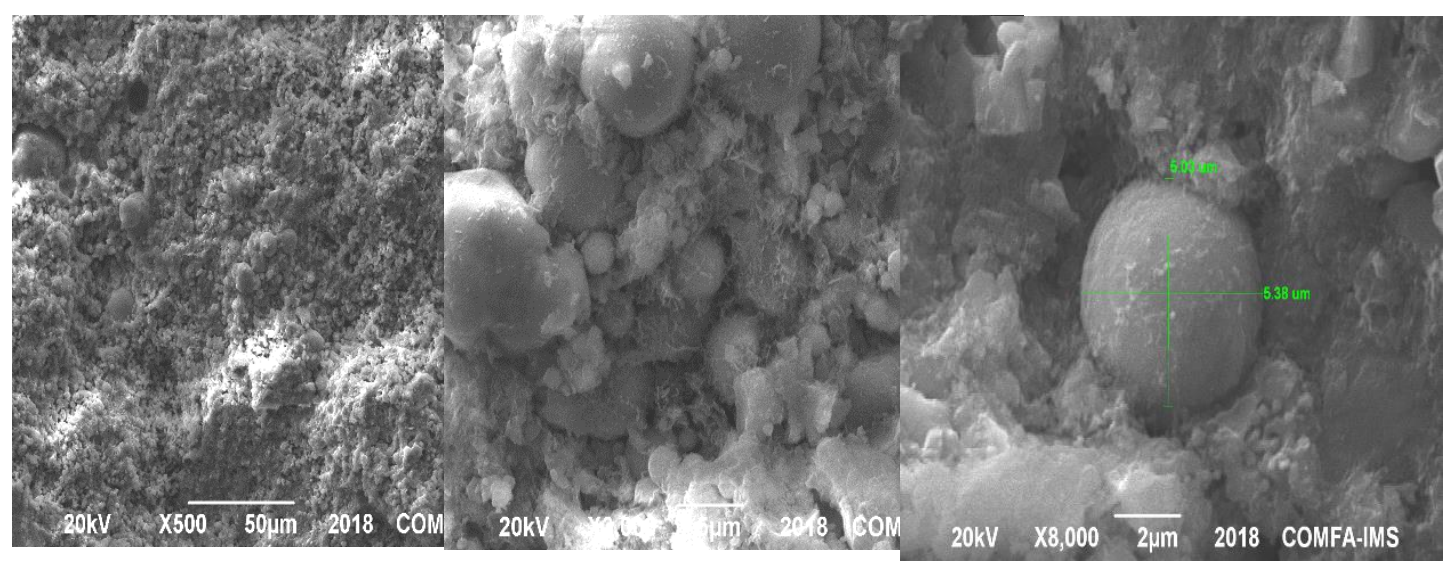

Fig. 3.7. SEM analysis of alumina cement contained $5 \%$ silica fume and polycarboxylate at 1 day

Minerals of ordinary alumina cement harden on Fig. 3.5 which shown to appear a lots of prismatic shape minerals of Gibbsit and gel of $\mathrm{CAH}\left(\mathrm{CaO} . \mathrm{Al}_{2} \mathrm{O}_{3} \cdot \mathrm{H}_{2} \mathrm{O}\right)$ and $\mathrm{CASH}(\mathrm{CaO}$. 
$\mathrm{Al}_{2} \mathrm{O}_{3} \cdot \mathrm{SiO}_{2} \cdot \mathrm{H}_{2} \mathrm{O}$ ) . For alumina cement contained fly ash and silica fume (shown on Fig. 3.6 and 3.7) was not disappear prismatic shape minerals of Gibbsit, that it is replaced by gel $(\mathrm{CAH}, \mathrm{CASH})$ cashed on surface of spherical, this Gel is formed creating on gel $\mathrm{SiO}_{2}$ $\mathrm{Al}_{2} \mathrm{O}_{3}$ from related by $\mathrm{SiO} 2$ (silica fume and fly ash) with $\mathrm{Al}_{2} \mathrm{O}_{3}$ it was hydrated product of alumina cement. This gel $\mathrm{SiO}_{2}-\mathrm{Al}_{2} \mathrm{O}_{3}$ was created high compressive strength on cement harden.

XRD analysis of alumina cement harden are shown on Fig. 3.8 to 3.10 and phases content are shown on Table 3.4

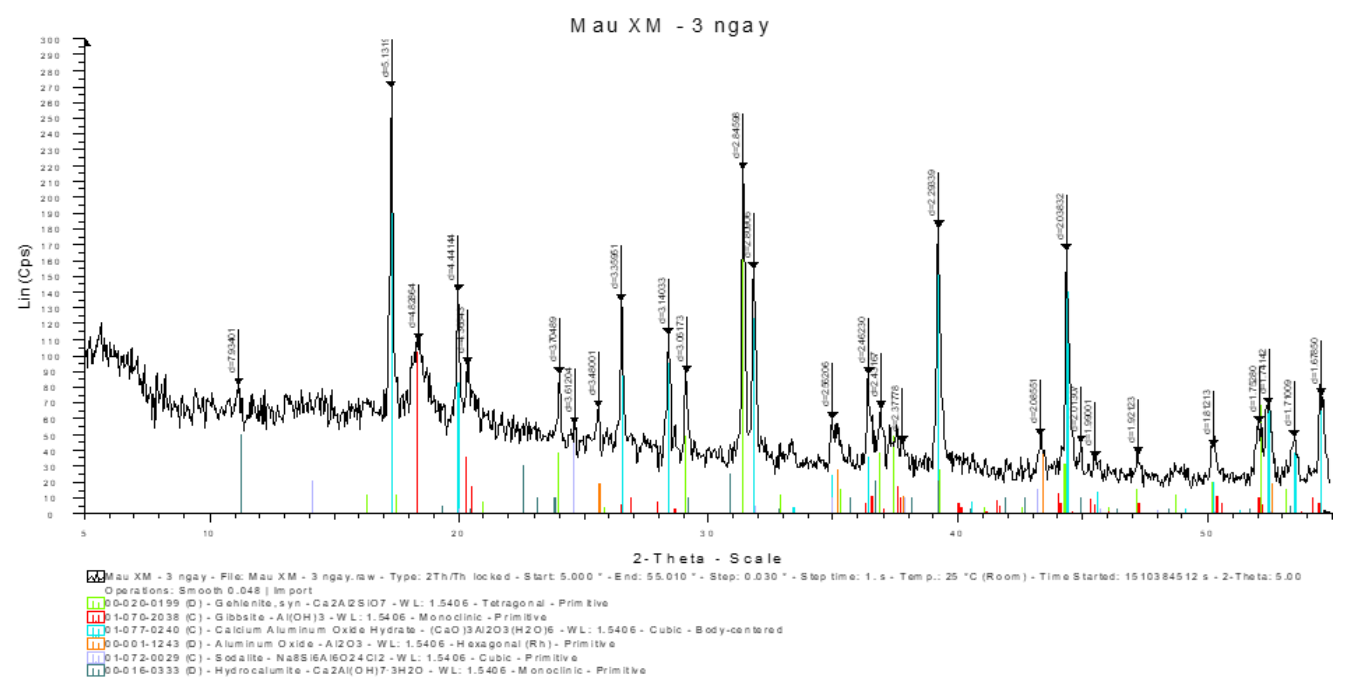

Fig. 3.8. XRD analysis of ordinary alumina cement at 3 days

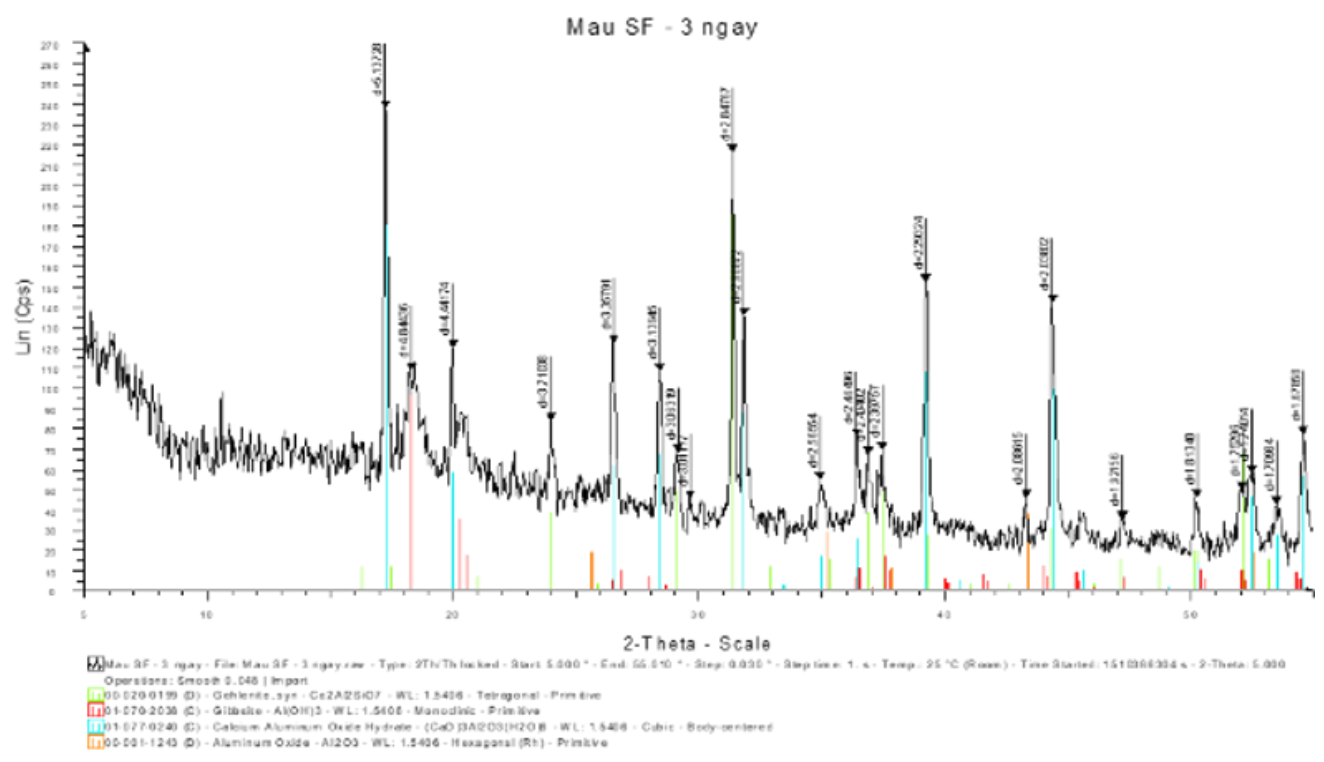

Fig. 3.9. XRD analysis of alumina cement contained $10 \%$ fly ash at 3 days 


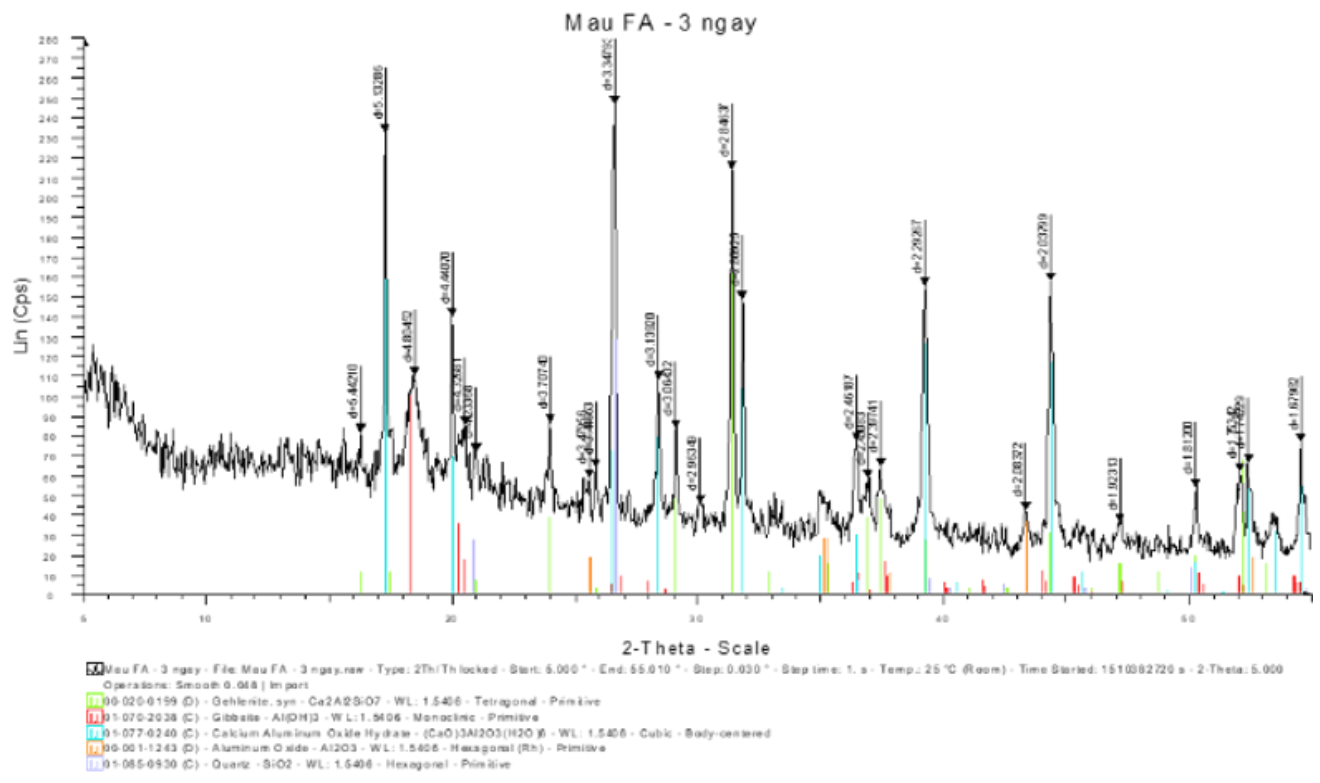

Fig. 3.10. XRD analysis of alumina cement contained 5\% silica fume at 3days

Table 3.4. The phases content of alumina cement harden

\begin{tabular}{|c|c|c|c|c|c|c|c|c|}
\hline $\begin{array}{c}\text { Sign } \\
\text { samp } \\
\text { le }\end{array}$ & $\begin{array}{c}\text { Quar } \\
\text { tz } \\
\mathrm{SiO}_{2}\end{array}$ & $\begin{array}{c}\text { Geheleni } \\
\text { te } \\
\mathrm{Ca} 3 \mathrm{Al3S} \\
{ }_{2} \mathrm{O}_{7}\end{array}$ & $\begin{array}{c}\text { Gibbs } \\
\text { ite } \\
A l(O \\
H)_{3}\end{array}$ & $\begin{array}{c}\text { Calcium } \\
\text { Aluminum } \\
\text { Oxide } \\
\text { Hydrate } \\
(\mathrm{CaO})_{3} \mathrm{Al}_{2} \mathrm{O}_{3}( \\
\left.\mathrm{H}_{2} \mathrm{O}\right)_{6} \\
\end{array}$ & $\begin{array}{c}\text { Alumin } \\
\text { um } \\
\text { Oxide } \\
\mathrm{Al}_{2} \mathrm{O}_{3}\end{array}$ & $\begin{array}{c}\text { Sodalite } \\
\mathrm{Na}_{8} \mathrm{Si}_{6} \mathrm{Al}_{6} \mathrm{O}_{2} \\
{ }_{4} \mathrm{Cl}_{2}\end{array}$ & $\begin{array}{c}\text { Hydrocalumi } \\
\text { te } \\
\mathrm{Ca}_{2} \mathrm{Al}(\mathrm{OH})_{7.3} \\
\mathrm{H}_{2} \mathrm{O}\end{array}$ & $\begin{array}{c}\text { Amorph } \\
\text { ous } \\
\text { phase }\end{array}$ \\
\hline $\begin{array}{l}\text { F10 } \\
-3 \\
\text { days }\end{array}$ & 6 & 20 & 16 & 24 & 6 & - & - & 27 \\
\hline $\begin{array}{c}\text { PF5- } \\
3 \\
\text { days }\end{array}$ & - & 21 & 16 & 27 & 7 & - & - & 29 \\
\hline $\begin{array}{l}0-3 \\
\text { days }\end{array}$ & - & 21 & 18 & 32 & 8 & 1 & 1 & 21 \\
\hline
\end{tabular}

XRD analysis of alumina cements harden (Fig. 3.8 to Fig 3.10) which shown mainly minerals as: Gelignite $\left(\mathrm{Ca}_{2} \mathrm{Al}_{2} \mathrm{SiO}_{7}\right)$ has specific peak as: $\mathrm{d}=3.710 ; 3.061 ; 2.845 ; 2.432$. Gibbsite $\mathrm{Al}(\mathrm{OH})_{3}$ has specific peak as: $\mathrm{d}=4.687 ; 4.361 ; 2.432 ; 1.812$. Calcium aluminum oxide hydrate $\left[\mathrm{Ca}_{2} \mathrm{Al}\left(\mathrm{H}_{2} \mathrm{O}\right)_{6}\right]$ has specific peak as: $\mathrm{d}=5.130 ; 4.447 ; 3.357 ; 3.140 ; 2.660$; 2.038 .

However, XRD analysis of alumina cement harden contained fly ash or silica fume (Table 3.10) which shown Gibbite and Aluminum oxide content reduced as: Ordinary alumina cement is $18 \%$ Gibbsite and $8 \%$ Aluminum Oxide., this phenomenon it has been proved that there was a reaction between amorphous silica of fly ash and silicafume with Gibbsite and Aluminum oxide of cement harden. 


\section{Conclusion}

The properties of alumina cement are greatly affected by the use fly ash, silica fume and polycarboxylate as:

1. The water requirement and setting time of cement paste which is reduced by the use fly ash, silica fume and polycarboxylate.

2. The compressive strength of cement harden is increased by the use of 5 to $10 \%$ fly ash content or from 5 to $15 \%$ silica fume content to replace by weight percentage of alumina cement.

3. The optimum compressive strength of cement hardens contained $5 \%$ fly ash content or $10 \%$ silica fume content to replace weight percentage and achieved early compressive strength at 3 days is over $85 \%$ compressive strength at 28 days.

\section{References}

1. A. Neville, P.J. Wainwright, High alumina cement concrete ( New York, 1992)

2. B. Pacewskaa, M. Nowackab, M. Aleknevičiusc, V. Antonovičd, Procedia Engineering, 57 ( 2013 )

3. F.W. Taylor, Cement chemistry, C 10 (1990)

4. H. Luu Thi, Technology research produces Alumina Cement AC50 from domestic materials of Viet Nam (Ministry of Construction, 2011)

5. J.S. Damtoft, J. Lukasik, D. Herfort, D. Sorrentino, E.M. Gartner, Cement and Concrete Research, 38 (2008)

6. L.J.J. Martin, F. Winnefeld, E. Tschopp, C. J. Muller, B. Lothenbach, Cement and concrete research, 95 (2017)

7. L. Fernández-Carrasco, J. Rius, Carles Miravitlles, Cement and Concrete Research, 38 (2008)

8. M.C.G. Juenger, F. Winnefeld, J.L. Provis, J.H. Ideker, Cement and Concrete Research . 41, (2011)

9. N. Ukrainczyk, T. Matusinović, Cement and concrete research, 40 (2009)

10. Onder Kirca, I. Ozgur Yaman, Mustafa Tokyay, Cement and concrete composites, 35 (2013)

11. P. F. Rumyatsev, V. S. Khotimchenko, V. M., Nikishenko, Hydration of aluminates of calcium (Leningrad, 1974)

12. T. V. Kuznetsova, I. Talaber, Alumina cement (M. Stroyizdat, 1988)

13. S.R. Klaus, J. Neubauer, F. Goetz-Neunhoeffer, Cement and Concrete Research, 43 (2013)

14. F. Hueller, D. Ectors, J. Neubauer, F. Goetz-Neunhoeffer, Cement and Concrete Research, 89 (2016)

15. X. Li, Y. Zhang, X. Shen, Q. Wang, Z. Pan, Cement and Concrete Research, 55 (2014) 